\title{
Evaluation of probiotic strain Bacillus subtilis C-3102 as a feed supplement for koi carp (Cyprinus carpio)
}

Suxu He ${ }^{1}$, Wenshu Liu ${ }^{1}$, Zhigang Zhou ${ }^{1 *}$, Wei Mao', Pengfei Ren¹, Toshihiro Marubashi ${ }^{1}$ and Einar Ring ${ }^{3}$

${ }^{1}$ Key Laboratory for Feed Biotechnology of the Ministry of Agriculture, Feed Research Institute, Chinese Academy of Agricultural Sciences, Beijing 100081, P. R. China ${ }^{2}$ Calpis Co., Ltd, Tokyo, Japan

${ }^{3}$ Norwegian College of Fishery Science, Faculty of Biosciences, Fisheries and Economics, University of Tromsø, 9037 Tromsø, Norway

\begin{abstract}
In this study, the effects of dietary probiotic Bacillus subtilis C-3102 (Calsporin ${ }^{\circledR}$ ) on the growth performance, predominant intestinal microbiota, expression of cytokines genes in three organs (liver, intestine and kidney) and protection against Aeromonas hydrophila infection of koi carp were investigated. Fish were fed two different diets, 1-control diet (non-supplemented) and 2-experimental diet (supplemented with $1 \mathrm{~g} / \mathrm{kg}$ Calsporin ${ }^{\circledR}$ ) for five weeks Tissue samples were collected at days 0,10,20 and 35. The results showed that the weight gain (WG) and feed conversion ratio (FCR) were significantly improved by dietary Bacillus subtilis $\mathrm{C}-3102(\mathrm{P}<0.01)$. Dietary probiotic did not affect the body skin colouration of koi carp $(P>0.05)$. Variation of intestinal bacterial communities were studied by denaturing gradient gel electrophoresis (DGGE) which revealed that even though Bacillus subtilis C-3102 was not detected as a prominent component in the intestinal tract of koi carp at any time point, it could affect the intestinal microbiota community at the early stages of the trial, becoming weaker in the later stages. Concerning the gene expression results, the expression of HSP70 gene was up-regulated at day 10 and 35 the liver; no effects were observed in the intestine and kidney. A general trend of upregulation of cytokines expression (IL-1 1 , IL-10, TNF- $\alpha$ and TGF- $\beta$ ) was observed in liver the (except IL-1 $\beta$ ) and intestine, but unchanged in the kidney (except IL-10). The intraperitoneal injection challenge demonstrated that there was no positive effect of dietary $B$. subtilis $\mathrm{C}-3102$ supplementation against $A$. hydrophila. These results suggested that $B$. subtilis $\mathrm{C}-3102$ can provide beneficial effects on growth, feed utilization and modulating intestinal microbiota community.
\end{abstract}

Keywords: Probiotic; Intestinal microbiota community; HSP70; Koi carp; Immune protection

\section{Introduction}

Probiotics in aquaculture have been reported to provide beneficial effects and now the use of probiotics is an important management tool in fish culture [1]. The positive effects of probiotic administration to fish growth and immune response are well-documented [2,3]. Probiotics may promote growth, non-specific immune responses, disease resistance and the survival rate of aquatic animals $[4,5]$.

Bacillus subtilis is a Gram positive, spore forming bacterium, used commercially in probiotic products because its beneficial effects have been documented and the pathogenic potential is generally described as low or absent [6]; moreover, as a spore former, Bacillus preparations are resistant and have a long lasting shelf life and thus can be stored in a state of dehydration [7]. B. subtilis can promote survival and growth [8], by stimulating the immune system [9] and by controlling pathogenic bacteria [10].

Theornamentalfish tradeis an economicallyimportant and profitable area of fish culture. The prosperity of the ornamental fish industry has induced the indiscriminate use of antibiotics and chemotherapeutants for improved health and nutrition, which has led to the development of drug-resistant strains of pathogenic microorganisms [11]. Koi carp is a high-value ornamental fish species. The benefits of probiotics on koi carp health, growth, and intestinal bacteria are well documented [12-14] but there are few reports investigating the variation intestinal microbiota community of koi carp treated with B. subtilis.

The aim of the present study was to evaluate the efficacy of Calsporin ${ }^{\circ}$, a probiotic based on viable spores of Bacillus subtilis C-3102, on growth performance, intestinal microbiota and cytokine regulation of koi carp. We chose HSP70 (heat shock protein), TGF- $\beta$ (transforming growth factor), IL-1 $\beta$ (interleukin-1 beta), TNF- $\alpha$ (tumour necrosis factor) and IL-10 (interleukin-10) genes in the liver, intestine and kidney to assess the effects of B. subtilis C-3102 on stress and immune responses. In addition, skin pigmentation, which is one of the most important quality criteria indictating koi carp market value, was measured. Finally, koi carps were challenged by Aeromonas hydrophila with intraperitoneal injection to determine the immune protection.

\section{Methods}

\section{Bacteria strain}

Calsporin ${ }^{\oplus}$ (Bacillus subtilis C-3102, live spore $\geq 1 \times 10^{10} \mathrm{cfu} / \mathrm{g}$ ) was supplied by Calpis Co., Ltd (Tokyo, Japan) and kept in a sterilized container prior to use.

\section{Diets and experimental design}

Sixteen tanks with eight replicate tanks per treatment were used. The formulation and chemical composition of the basal diet (which served as the control diet) is shown in Table 1. These ingredients were mixed, extruded and air-dried at room temperature. The experimental diet was prepared using the basal formulation with the supplementation of $1 \mathrm{~g} /$ $\mathrm{kg}$ of Calsporin ${ }^{\oplus}$ (containing $>1 \times 10^{10} \mathrm{cfu} / \mathrm{g}$ Bacillus subtilis C-3102

*Corresponding author: Zhigang Zhou, Key Laboratory for Feed Biotechnology of the Ministry of Agriculture, Feed Research Institute, Chinese Academy of Agricultural Sciences, No.12 Zhongguancun South Street, Beijing 100081, P. R. China, Tel: +86 10 82106053; fax: +86 10 82106054; E-mail: zhou_zg@msn.com

Received June 30, 2011; Accepted October 11, 2011; Published October 15 2011

Citation: He S, Liu W, Zhou Z, Mao W, Ren P, et al. (2011) Evaluation of probiotic strain Bacillus subtilis C-3102 as a feed supplement for koi carp (Cyprinus carpio). J Aquac Res Development S1:005. doi:10.4172/2155-9546.S1-005

Copyright: ( $2011 \mathrm{He} \mathrm{S}$, et al. This is an open-access article distributed under the terms of the Creative Commons Attribution License, which permits unrestricted use, distribution, and reproduction in any medium, provided the original author and source are credited. 
Citation: He S, Liu W, Zhou Z, Mao W, Ren P, et al. (2011) Evaluation of probiotic strain Bacillus subtilis C-3102 as a feed supplement for koi carp (Cyprinus carpio). J Aquac Res Development S1:005. doi:10.4172/2155-9546.S1-005

Page 2 of 7

spores). The diets were presented to the fish as pellets. Feeds were stored in a cool dry place until used. Table 2 shows the experimental design. The dietary level of viable $B$. subtilis was enumerated on selective medium. Briefly, approximately $1 \mathrm{~g}$ feed was homogenized in $100 \mathrm{~mL}$ of deionized water containing $0.05 \%$ Tween 20 . Serial dilutions were made and spread onto plates of $B$. subtilis-selective medium and incubated for $3 \mathrm{~d}$ at $24{ }^{\circ} \mathrm{C}$. The selective medium consisted of $326 \mathrm{~mL}$ vegetable juice (V8, Campbell Soup Co., USA), $33 \mathrm{~g} \mathrm{NaCl}, 0.8 \mathrm{~g}$ dextrose, 490 $\mathrm{mL}$ water, and $16 \mathrm{~g}$ agar, with the $\mathrm{pH}$ adjusted to $5.2 \mathrm{using} \mathrm{NaOH}$ [15]. Forty-five mg of cyclohexamide and $22.5 \mathrm{mg}$ of polymixin B were added to each liter of medium to inhibit fungi and Gram-negative bacteria, respectively. Populations were reported as cfu/g feed. Juvenile koi carp were transported from a private hatchery (Beijing, China) to the Feed Research Institute, Chinese Academy of Agricultural Sciences. All fish were fed the basal diet for 2 weeks to acclimate to the experimental conditions. After the acclimation, 384 fish (initial body weight $4.48 \pm$ $0.02 \mathrm{~g}$ ) were randomly assigned to sixteen 100-L tanks (eight replicate groups per dietary treatment) at a density of 24 fish per tank. The tanks were part of a recirculation system, and $10 \%$ of the water was exchanged daily. During the experiment, the temperature ranged from 23 to $26^{\circ} \mathrm{C}$, dissolved oxygen (DO) ranged from 5.6 to $7.8 \mathrm{mg} / \mathrm{L}, \mathrm{pH}$ was $7.82 \pm 0.05$ and the total ammonium and nitrite were kept below 0.1 and 0.05 , respectively.

Fish were fed twice daily at 9:00 and 15:00 at $1-2 \%$ body weight per day. After feeding, uneaten food from each tank was removed by siphoning to calculate feed utilization.

\section{Morphometric analysis and survival rate}

At the beginning and end of the 35 day trial, fish were batch weighed. At the same time, the total numbers of remaining juveniles were counted and survival rate was calculated. In addition, the color index was measured by the SalmoFan ${ }^{\text {Tx }}$ Lineal based on the surface erythema.

The weight gain (\%) was calculated as:

$\frac{\text { final weight }(\mathrm{g}) \text { - initial weight }(\mathrm{g})}{\text { initial weight }(\mathrm{g})} \times 100 \%$

The feed conversion ratio (FCR) was calculated as:

total feed consumption (total feed casting - total food residue) $(\mathrm{g})$ total final weight $(\mathrm{g})$ - total initial weight $(\mathrm{g})+$ total morality weight $(\mathrm{g}) \times 100 \%$

\begin{tabular}{ll}
\hline Ingredient & Percentage (\%) \\
\hline Fish meal & 47.0 \\
Soybean meal & 24.0 \\
Wheat flour & 24.0 \\
Soybean oil & 2.0 \\
$\mathrm{Ca}\left(\mathrm{H}_{2} \mathrm{PO}_{4}\right)_{2}$ & 2.2 \\
Vitamin C phosphate ester & 0.1 \\
Choline chloride & 0.3 \\
Vitamin mix & 0.2 \\
Mineral mix & 0.2 \\
\hline Chemical composition & \\
\hline Crude protein & 42.0 \\
Crude lipid & 7.3 \\
\hline
\end{tabular}

Table 1: Diet formulation and chemical composition of the basal diet.

\begin{tabular}{lll}
\hline Treatment & Diet & Calsporin $^{\circledast}(\mathrm{g} / \mathrm{kg}$ feed $)$ \\
\hline Control & Basal & 0 \\
Calsporin $^{\circledR}$ & Basal + Calsporin ${ }^{\circledR}$ & 1 \\
\hline
\end{tabular}

Table 2: The experimental treatments.

\section{Intestinal microbial analyses}

Three fish per tank were sampled at day $0,10,20,35$ for intestinal microbial analysis using the method described by Zhou et al. [16]. Intestines of the koi carp were aseptically taken out, opened, and gently agitated thrice for $1 \mathrm{~min}$ in phosphate-buffered saline (PBS: $130 \mathrm{mM}$ $\mathrm{NaCl}, 10 \mathrm{mM} \mathrm{NaH}_{2} \mathrm{PO}_{4}, \mathrm{pH}$ 7.2) to remove the contents. Genomic DNA was obtained using the extraction method described by $\mathrm{Yu}$ and Morrison [17]. The target sequence (V3 region of gene ssr) was amplified by PCR using primers 338f (5'-ACTCCTACGGGAGGCAGCAG-3') and 519r (5'-ATTACCGCGGCTGCTGG-3') for DGGE. DGGE gels were stained with ethidium bromide solution $(5 \mu \mathrm{g} / \mathrm{mL} ; 20 \mathrm{~min})$, washed with deionized water, and viewed by UV transillumination. Computerassisted comparison of DGGE banding patterns was performed with BIO-1 D++ gel analysis software (VilberLourmat, Torcy, France). Cluster analysis was based on the unweighted pair group method using the arithmetic mean algorithm (UPGMA). The excised bands were reamplified and purified, then sequenced.

\section{Gene expression analyses}

Three fish per tank were sampled for liver, kidney and intestinal gene expression analysis at day $0,10,20$ and 35 , respectively. To reduce individual variation of gene expression, the sampled fish organs from each tank were pooled and homogenized using a glass homogenizer Total RNA was extracted using a TRIzon Reagent RNA kit according to the manufacturer's instructions (Promega, Germany), thereafter the quality was analyzed on a $1.2 \%$ agarose gel. RNA was dissolved in $50 \mu \mathrm{L}$ RNase-Free water and stored at $-80^{\circ} \mathrm{C}$ until use. The reverse transcription polymerase chain reaction (RT-PCR) was performed by using Rever Tra Ace- $\alpha$-RT-PCR kit (TOYOBO, Shanghai, China) according to the manufacturer's instructions.

The RT-PCR primers were cautiously designed using Primer premier 5.0 software based on the available sequences in GenBank (Table 3), the primers were designed on the following principles: 1) the PCR product should be between 200 and $500 \mathrm{bp}, 2$ ) the GC content within $40-60 \%$, and 3) the annealing temperature is between $58-60^{\circ} \mathrm{C}$. The qPCRs were performed with the SYBR Green Premixus Ex Taq TMII (TaKaRa, Beijing, China) in an iQ5 multicolor real time PCR Detection system (Bio-Rad). The total volume of PCR was $20 \mu \mathrm{L}$ and consisted of: $10 \mu \mathrm{L}$ SYBR Green Premix Ex TaqII $(2 \times), 1 \mu \mathrm{L}$ primer of each, $2 \mu \mathrm{L}$ cDNA and $6 \mu \mathrm{L}$ ddH2O. The cycling conditions were as follows: $95^{\circ} \mathrm{C} 3 \mathrm{~min}$ and then 40 cycles of $95^{\circ} \mathrm{C} 20,55^{\circ} \mathrm{C} 20 \mathrm{~s}$ and $72^{\circ} \mathrm{C}$ 20s. All real-time PCRs were performed at least in triplicate. Data analysis was conducted using the $2^{-\Delta \Delta C T}$ method [18], and 40S gene was chosen as internal standard.

\section{Assessment of the protective effect of probiotic on Aeromonas hydrophila infection}

Aeromonas hydrophila NJ-1 was obtained from a natural outbreak in one of the culture ponds at the facility and donated by Professor Yongjie Liu (Nanjing Agricultural University, Nanjing, China). After the 35 day feeding experiment, carp were infected by $A$. hydrophila NJ-1 by an intraperitoneal injection of $50 \mu \mathrm{L}$ at a dose of $10^{7} \mathrm{cfu} / \mathrm{mL}$. The Protective effects were evaluated by recording the accumulated mortalities over 7 days.

\section{Statistical analysis}

Results are expressed as the mean \pm S.D. Difference between groups were determined using a paired t-test with the statistical software package SPSS 17.0. Significant differences were accepted at $P<0.05$. 
In this study, a change in the expression of mRNA level by more or less than $50 \%$, relative to baseline levels (i.e. day 0 ) is regarded as significant difference.

\section{Results}

\section{Growth performance}

The koi carp survival rate during the nutrition trial was $100 \%$ after 35 days. Data on growth performance and feed utilization including final body weight (FBW), relative weight gain (WG), feed conversion ratio (FCR) and survival rate (SR) are shown in Table 4. The mean final weight of the probiotic group was significantly higher $(P<0.05)$ than that of the control group. The relative WG of the probiotic group was significantly higher $(P<0.05)$ than that of the control group, moreover, the probiotic group presented lower FCR than that of control group.

The body surface colour index of koi carp is presented in Table 5. The mean value of the colour index of the probiotic fed fish was not significantly different to that of the control fed fish.

\section{Intestinal microbial analyses}

The 16S rDNA-V3 PCR-DGGE fingerprints of the intestinal autochthonous bacterial communities of the experimental koi carp are showed in Figure 1. Thirty two different bands from the DGGE gel were excised and the eluted DNA subjected to PCR and successful sequencing. The closest relative (obtained from BLAST search) of bacteria excised from the 16S V3 PCR-DGGE are presented in Table 6.

Obvious variation of the bacterial communities members were observed, especially at day 20 and 35 . The visual band numbers for the initial fish, B. subtilis C-3102 treatment (T) and the control group (CK) are as follows: initial (20), CK10 (18), T10 (18), CK20 (12), T20 (10), CK35 (11) and T35 (11). The potential pathogenic bacteria such as Vibrio cholerae (band 4), Aeromonas sp. (band 24), Aeromonas jandaei (band 30) were not present at day 10; the abundance of Plesiomonas shigelloides was reduced at day 10 in the probiotic group, and then disappeared at days 20 and 35; Aeromonas sp. (band 21, 24), Aeromonas veronii (band 29), Aeromonas jandaei (band 30) were not detected in any groups at day 20. But another pathogenic bacteria, Vibrio cholerae (band 12), was detected from day 20 in all groups. In addition, B. subtilis C-3102 wasn't detected in either treatment at any time point. However, the concentration of B. subtilis C-3102 in the feed was $9.3 \times 10^{6} \mathrm{cfu} / \mathrm{g}$ at the end of the experiment in the probiotic diet (B. subtilis C-3102 was absent in the control diet).
The similarity coefficients of the treatments are shown in Figure 2. The similarity coefficients between the dietary B. subtilis C-3102 treatment and the control group gradually increased. In particular at day 35 , the similarity coefficients exceeded 0.90 . These results indicated that the effect of dietary B. subtilis C-3102 on intestinal microbiota of koi carp decreased with time/feeding duration in this study.

\section{mRNA analysis by Real-time PCR}

The expression of the IL- $1 \beta$, TNF- $\alpha$, HSP70, TGF- $\beta$, IL-10 genes were evaluated at day $0,10,20$, and 35 in the liver, intestine and kidney to investigate the effects of $B$. subtilis C-3102 on immunity and stress at the molecular level.

In the liver (Figure 3a), dietary B. subtilis C-3102 caused a small, but significant increase in TNF- $\alpha$ and TGF- $\beta$ mRNA levels at days 35 relative to day 0 , also in HSP70 mRNA level at days 10 and 35, and in IL-10 mRNA level at days 20 . However, IL- $1 \beta$ mRNA production was significantly down-regulated at day 10 .

In the intestine (Figure $3 \mathrm{~b}$ ), a significant increase was detected in IL- $1 \beta$, TNF- $\alpha$ and TGF- $\beta$ gene expression at day 20 and 35. IL-10 gene expression was significantly increased at day10, 20 and 35. But IL- $1 \beta$ mRNA production was significant down-regulated at day 10 . No significant effect was observed to HSP70 gene expression.

In the kidney (Figure 3c), IL-1 $\beta$ gene expression level was significantly reduced at day 35 , and TGF was significantly downregulated at day 10 compared to initial levels. No significant effects were detected for TNF- $\alpha$ or HSP70 gene expression.

\section{Immune protection against disease}

The result of survival rate 7 days after the Aeromonas hydrophila challenge is displayed in Figure 4. No significant difference $(P>0.05)$ was detected between the CK and treated trials. This result suggests that Bacillus subtilis C-3102 could not enhance the immune protection to a great enough extent to protect against the A. hydrophila in the present challenge model.

\section{Discussion}

Probiotics have been applied as dietary additives or water additives to improve growth performance and immune response of experimental fish. With the development of the ornamental fish trade, more investigations of the effects of probiotics on ornamental fish have been conducted [19-22]. Spores of Bacillus strains are thermo-stabile which

\begin{tabular}{|c|c|c|c|}
\hline Gene name & Primer sequences & Product size (bp) & Genebank number \\
\hline IL-10 & $\begin{array}{l}\text { F:GCACCATTACTCGATGAAAACG } \\
\text { R:CTGGCGAACTCAAAGGGATT }\end{array}$ & 236 & JF957369 \\
\hline TNF- $\alpha$ & $\begin{array}{l}\text { F: GCCATAGGAATCAGAGTAGCG } \\
\text { R: GACCAGGCTTTCACTTCAGG }\end{array}$ & 183 & JF957372 \\
\hline HSP70 & $\begin{array}{l}\text { F: CACAATCACCAACGATAAGGG } \\
\text { R: TTGGCAGACACCTTTTCACGC }\end{array}$ & 114 & JF957366 \\
\hline TGF- $\beta$ & $\begin{array}{l}\text { F: CCTGGGCTGGAAGTGGATAC } \\
\text { R:GTAAAAGATGGGCAGTGGGTC }\end{array}$ & 190 & JF957371 \\
\hline $40 S$ & $\begin{array}{l}\text { F:GTTGTACTTGCGGATGTAATGC } \\
\text { R:TGGCTGTTGAAGGAAGTGGC }\end{array}$ & 233 & JF957364 \\
\hline
\end{tabular}

Table 3: Primer sequences for QPCR.

\begin{tabular}{lllll}
\hline & IBW $(\mathrm{g})$ & FBW $(\mathrm{g})$ & WG $(\%)$ & FCR \\
\hline Control & $4.49 \pm 0.01$ & $11.20 \pm 0.21$ & $149.61 \pm 4.69$ & $1.41 \pm 0.06$ \\
Calsporin $^{\circledR}$ & $4.47 \pm 0.02$ & $11.73 \pm 0.38^{* *}$ & $162.13 \pm 8.22^{* *}$ & $1.31 \pm 0.04^{* *}$ \\
\hline
\end{tabular}

** $p<0.01$.

Table 4: Effects of dietary Bacillus subtilis C-3102 on the growth performance, diet conversion and survival rate of koi carp. 
Citation: He S, Liu W, Zhou Z, Mao W, Ren P, et al. (2011) Evaluation of probiotic strain Bacillus subtilis C-3102 as a feed supplement for koi carp (Cyprinus carpio). J Aquac Res Development S1:005. doi:10.4172/2155-9546.S1-005

\begin{tabular}{ll}
\hline & Color index \\
\hline Control & $27.8 \pm 1.2$ \\
Calsporin $^{\circledR}$ & $26.2 \pm 2.0$
\end{tabular}

${ }^{\$}$ Color index was measured by the SalmoFan ${ }^{\mathrm{TM}}$ Lineal based on the surface erythema.

Table 5: Effect of dietary Bacillus subtilis C-3102 on the body surface color of koi carp\$.

makes them easy to incorporate into compound diets. In this particular instance, diets supplemented with B. subtilis $\mathrm{C}-3102$ spores resulted in growth performances and feed utilization of koi carp significantly better than that of the koi carp fed the control basal diets (Table 4). Thus, indicating growth improving properties of the probiotic Calsporin. Similar results were also observed in studies on gilthead seabream (Sparus aurata L.) [19,23], tilapia (Oreochromis niloticus) [24] and large yellow croaker (Larimichthys crocea) [9]. These studies show that the Bacillus sp. can improve fish growth performance, immune response and digestive enzyme activity. In the present study, the administration of the probiotic had no effect on survival (Table 4) of koi carp or skin pigmentation (Table 5).

In the present study, the DGGE profile (Figure 1) and sequencing results (Table 6) showed that the intestinal bacteria varied with culturing time. Species such as Vibrio cholerae and Aeromonas spp. only appeared at the beginning experiment; some Vibrio, Plesiomonas, Cetobacterium, Escherichia and Aeromonas species were detected only on day 10 and some uncultured and Acinetobacter bacteria appeared only at day 20 .
Furthermore, the number of autochthonous strains was dramatically decreased on day 20 and 35 compared to the initial or day 10 levels. The intestinal bacterial flora of hybrid tilapia cultured in earthen ponds has been reported to vary with seasonal changes: Al-Harbi \& Uddin [25] reported that Pseudomonas spp. were found only in winter while other bacteria (e.g. Photobacterium damselae, Pasteurella spp., Cellulomomus sp. and Bacillus sp.) were present in some other seasons of the year. The observation of hybrid tilapia intestinal autochthonous bacterial variations over feeding period has also been reported [26]. In our study, Aeromonas veronii appeared at the initial and day 10 of control group, which were inhibited by dietary B. subtilis C-3102 (as indicated by their absence in the DGGE profiles of the probiotic group at all time points). A. veronii is a pathogenic bacteria which can cause fish mortalities [27]. Previous studies have also reported that dietary probiotics can reduce levels of potential pathogenic bacteria in the GI tract of fish $[24,28]$. Therefore, microbial manipulation constitutes a viable tool to reduce or eliminate the incidence of opportunistic pathogens [29]. The probiotics B. subtilis C-3102 was not observed as one of the dominant (i.e. was not detected) species in the GI tract of the probiotic fed fish at any timepoint. This similar phenomenon has also been oberved in a previous study which showed that dietary Bacillus toyoi could not be detected in the intestine of European eels (Anguilla anguilla L.) [30]. The different effects of probiotics on GI microbiota may be attributed to the different mechanisms of action of probiotics. Mechanisms of microbiota modulation by probiotics include: (1) competition for attachment sites and space, (2) competition for nutrients, (3) production of antimicrobial substances, and (4) enhancement of the

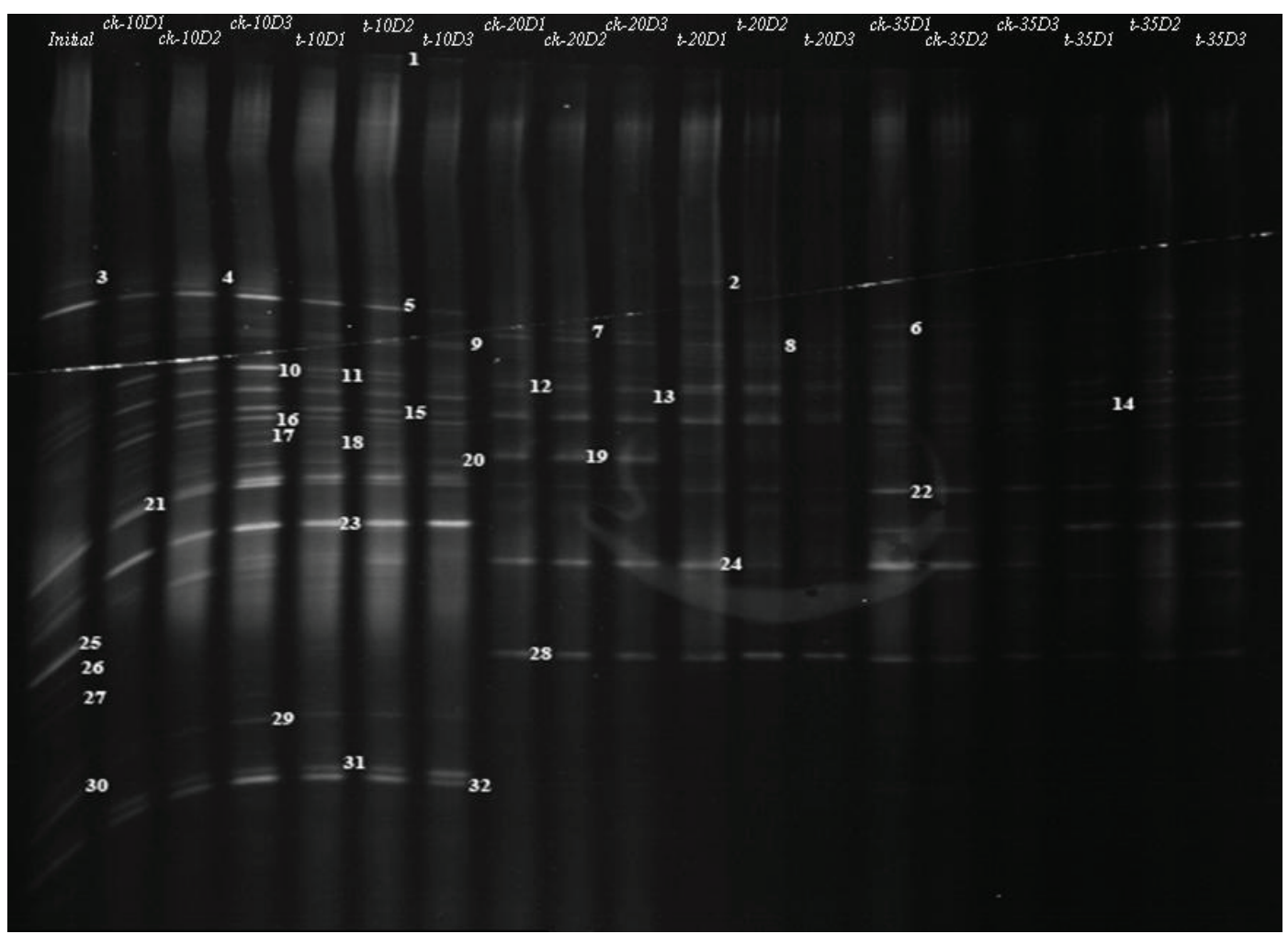

Figure 1: Effects of dietary Bacillus subtilis C-3102 on the intestinal autochthonous microbiota of koi carp by $16 \mathrm{~S}$ rDNA v3 Denaturing Gradient Gel Electrophoresis (DGGE).

Initial: the initial sample; $c k-10 D 1-3$ : the triplicates of the control at the end of 10 feeding days; t-10D1-3: the triplicates of the Bacillus subtilis C-3102 treatment at the end of 10 feeding days; ck-20D1-3: the triplicates of the control at the end of 20 feeding days; $t-20 D 1-3$ : the triplicates of the Bacillus subtilis C-3102 treatment at the end of 20 feeding days; ck-35D1-3: the triplicates of the control at the end of 35 feeding days; $t$-35D1-3: the triplicates of the Bacillus subtilis C-3102 treatment at the end of 35 feeding days. 1-32: the band number. 
Citation: He S, Liu W, Zhou Z, Mao W, Ren P, et al. (2011) Evaluation of probiotic strain Bacillus subtilis C-3102 as a feed supplement for koi carp (Cyprinus carpio). J Aquac Res Development S1:005. doi:10.4172/2155-9546.S1-005

Page 5 of 7

\begin{tabular}{|c|c|c|c|c|c|c|c|c|c|}
\hline \multirow[t]{2}{*}{ Band No. } & \multirow{2}{*}{$\begin{array}{c}\text { Closest relative (obtained from } \\
\text { BLAST search) }\end{array}$} & \multirow[t]{2}{*}{ Identity (\%) } & \multicolumn{7}{|c|}{ Relative abundance (RA, \%) } \\
\hline & & & Initial & ck-10D & $t-10 D$ & ck-20D & $\mathrm{t}-20 \mathrm{D}$ & ck-35D & $t-35 D$ \\
\hline 1 & $\begin{array}{l}\text { Uncultured Ferrimonas sp. } \\
\text { (HQ914736.1) }\end{array}$ & 99 & 0 & 0.0 & $0.9 \pm 0.5$ & $1.1 \pm 0.5$ & $2.1 \pm 1.4$ & $0.9 \pm 0.7$ & $1.5 \pm 0.6$ \\
\hline 2 & $\begin{array}{l}\text { Uncultured Mollicutes bacterium } \\
\text { (HM749044.1) }\end{array}$ & 100 & 0 & 0.0 & 0.0 & 0.0 & $1.6 \pm 2.3$ & 0.0 & 0.0 \\
\hline 3 & $\begin{array}{l}\text { Uncultured bacterium } \\
\text { (EU468590.1) }\end{array}$ & 96 & 3.2 & 0.0 & 0.0 & 0.0 & 0.0 & 0.0 & 0.0 \\
\hline 4 & Vibrio cholerae (GQ359963.1) & 100 & 0 & $0.8 \pm 0.5$ & $0.6 \pm 0.2$ & 0.0 & 0.0 & 0.0 & 0.0 \\
\hline 5 & $\begin{array}{l}\text { Plesiomonas shigelloides } \\
\text { (HM007572.1) }\end{array}$ & 100 & 20.6 & $10.9 \pm 2.5$ & $2.9 \pm 0.3$ & 0.0 & 0.0 & 0.0 & 0.0 \\
\hline 6 & $\begin{array}{l}\text { Uncultured bacterium } \\
\text { (EU468590.1) }\end{array}$ & 96 & 0 & 0.0 & 0.0 & 0.0 & 0.00 & $4.90 \pm 0.93$ & $3.4 \pm 1.5$ \\
\hline 7 & Acinetobacter sp. (HM582679.1) & 100 & 0 & 0.0 & 0.0 & $0.4 \pm 0.3$ & $0.6 \pm 0.9$ & 0.0 & 0.0 \\
\hline 8 & $\begin{array}{l}\text { Uncultured bacterium } \\
\text { (EU468590.1) }\end{array}$ & 96 & 0 & 0.0 & 0.0 & $4.2 \pm 1.1$ & $4.0 \pm 1.8$ & $4.4 \pm 1.5$ & $2.3 \pm 1.0$ \\
\hline 9 & $\begin{array}{l}\text { Cetobacterium somerae } \\
\text { (AB353124.1) }\end{array}$ & 100 & 1.4 & $5.0 \pm 2.1$ & $2.3 \pm 0.6$ & 0.0 & 0.0 & 0.0 & 0.0 \\
\hline 10 & $\begin{array}{l}\text { Uncultured bacterium } \\
\text { (EU469094.1) }\end{array}$ & 94 & 2.3 & $9.9 \pm 3.2$ & $1.0 \pm 0.4$ & $1.1 \pm 1.0$ & 0.0 & 0.0 & 0.0 \\
\hline 11 & Cetobacterium sp. (HM778168.1) & 100 & 0.3 & $0.4 \pm 0.1$ & $0.3 \pm 0.05$ & 0.0 & 0.0 & 0.0 & 0.0 \\
\hline 12 & Vibrio cholerae (GQ359963.1) & 100 & 0 & 0.0 & 0.0 & $6.4 \pm 1.4$ & $9.8 \pm 4.1$ & $4.3 \pm 2.3$ & $4.9 \pm 2.6$ \\
\hline 13 & $\begin{array}{l}\text { Uncultured bacterium } \\
\text { (HM749031.1) }\end{array}$ & 99 & 0 & 0.0 & 0.0 & $0.97 \pm 0.42$ & 0.0 & 0.0 & $3.2 \pm 0.4$ \\
\hline 14 & $\begin{array}{l}\text { Uncultured bacterium } \\
\text { (HQ905034.1) }\end{array}$ & 100 & 1 & $10.6 \pm 5.8$ & $3.5 \pm 0.9$ & $12.2 \pm 2.5$ & 0.0 & $2.3 \pm 1.8$ & $6.0 \pm 2.7$ \\
\hline 15 & $\begin{array}{l}\text { Uncultured bacterium } \\
\text { (HM749031.1) }\end{array}$ & 100 & 1.4 & $5.3 \pm 2.3$ & 3. $7 \pm 2.4$ & $8.6 \pm 1.5$ & $15.0 \pm 3.4$ & $8.4 \pm 1.0$ & 0.0 \\
\hline 16 & Vibrio sp. (AB182229.1) & 100 & 1.2 & $4.5 \pm 1.6$ & $1.6 \pm 0.2$ & 0.0 & 0.0 & $3.4 \pm 2.3$ & $7.4 \pm 1.5$ \\
\hline 17 & $\begin{array}{l}\text { Uncultured bacterium } \\
\text { (HM778780.1) }\end{array}$ & 98 & 0 & $5.4 \pm 3.7$ & $1.5 \pm 0.2$ & 0.0 & 0.0 & 0.0 & 0.0 \\
\hline 18 & $\begin{array}{l}\text { Cetobacterium somerae } \\
\text { (AB353124.1) }\end{array}$ & 100 & 0.9 & $4.3 \pm 3.1$ & $1.8 \pm 0.3$ & 0.0 & 0.0 & 0.0 & 0.0 \\
\hline 19 & $\begin{array}{l}\text { Uncultured bacterium } \\
\text { (AB179538.1) }\end{array}$ & 96 & 0 & 0.0 & 0.0 & $10.9 \pm 1.4$ & 0.0 & 0.0 & 0.0 \\
\hline 20 & $\begin{array}{l}\text { Escherichia fergusonii } \\
\text { (HQ259962.1) }\end{array}$ & 100 & 1.2 & $2.4 \pm 0.4$ & $3.7 \pm 0.9$ & 0.0 & 0.0 & 0.0 & 0.0 \\
\hline 21 & Aeromonas sp. (HQ841071.1) & 100 & 0.5 & $2.0 \pm 1.3$ & $3.0 \pm 1.0$ & 0.0 & 0.0 & 0.0 & 0.0 \\
\hline 22 & $\begin{array}{l}\text { Uncultured bacterium } \\
\text { (GU531301.1) }\end{array}$ & 100 & 3.9 & $9.2 \pm 4.4$ & $13.1 \pm 2.6$ & $5.67 \pm 0.88$ & $9.7 \pm 5.4$ & $18.8 \pm 3.3$ & $11.9 \pm 5.0$ \\
\hline 23 & $\begin{array}{l}\text { Uncultured Mollicutes bacterium } \\
\text { (HM749044.1) }\end{array}$ & 100 & 29.8 & $24.5 \pm 3.7$ & $33.8 \pm 4.5$ & 0.0 & $14.9 \pm 2.4$ & $9.8 \pm 2.0$ & $21.9 \pm 3.1$ \\
\hline 24 & Aeromonas sp. (HQ841071.1) & 100 & 1.3 & $2.0 \pm 0.5$ & $2.0 \pm 0.6$ & $30.6 \pm 2.1$ & $21.8 \pm 10.3$ & $27.2 \pm 1.0$ & $20.1 \pm 1.8$ \\
\hline 25 & $\begin{array}{l}\text { Uncultured Exiguobacterium sp. } \\
\text { (HM749032.1) }\end{array}$ & 100 & 15.7 & 0.0 & 0.0 & 0.0 & 0.0 & 0.0 & 0.0 \\
\hline 26 & Acinetobacter sp. (HQ684847.1) & 100 & 1.4 & 0.0 & 0.0 & 0.0 & 0.0 & 0.0 & 0.0 \\
\hline 27 & $\begin{array}{l}\text { Uncultured Mollicutes bacterium } \\
\text { (HM749044.1) }\end{array}$ & 98 & 2.1 & 0.0 & 0.0 & 0.0 & 0.0 & 0.0 & 0.0 \\
\hline 28 & Acinetobacter sp. (FR749840.1) & 95 & 0 & 0.0 & 0.0 & $18.2 \pm 1.6$ & $21.2 \pm 7.3$ & $16.3 \pm 4.1$ & $18.3 \pm 2.4$ \\
\hline 29 & Aeromonas veronii (HQ832864.1) & 99 & 0.6 & $0.4 \pm 0.5$ & 0.0 & 0.0 & 0.0 & 0.0 & 0.0 \\
\hline 30 & Aeromonas jandaei (HQ683971.1) & 100 & 0.9 & 0.0 & 0.0 & 0.0 & 0.0 & 0.0 & 0.0 \\
\hline 31 & Acinetobacter sp. (HM582678.1) & 100 & 0 & $4.2 \pm 0.5$ & $10.6 \pm 0.9$ & 0.0 & 0.0 & 0.0 & 0.0 \\
\hline 32 & $\begin{array}{l}\text { Bacterium DC21(2011) } \\
\text { (HQ178949.1) }\end{array}$ & 100 & 13.3 & $6.0 \pm 5.1$ & $14.2 \pm 2.5$ & 0.0 & 0.0 & 0.0 & 0.0 \\
\hline
\end{tabular}

Table 6: Representative of bacteria or clones and their relative abundance (RA, \%) isolated from the gut wall of Koi carp fed Bacillus subtilis C-3102.

immune response against pathogenic microorganisms [1]. But the exact mechanisms and the interactions between the host and microbe, microbe and microbe, are still unknown.

Fish growth is strictly related to environmental conditions, where improper captive rearing conditions induce stress and may negatively affect fish welfare. HSP genes, in particular HSP70, play essential roles in stress tolerance. A lower level of HSP70 gene expression was reported in Gilthead sea bream larvae fed on live prey enriched with probiotics (composed of three Bacillus strains) at both day 47 and 75 post hatch which indicated that a positive role of this mix of Bacillus reducing the severity of cellular stress [24]. In the present study, the HSP70 gene expression level was up-regulated in the liver at day 10 but reduced thereafter; no effects were exhibited in intestine and kidney of koi carp treated with the probiotic.

TGF- $\beta$, TNF- $\alpha$, IL-1 $\beta$ (all pro-inflammatory) and IL-10 (antiinflammatory) are inflammatory cytokines that play an important role 


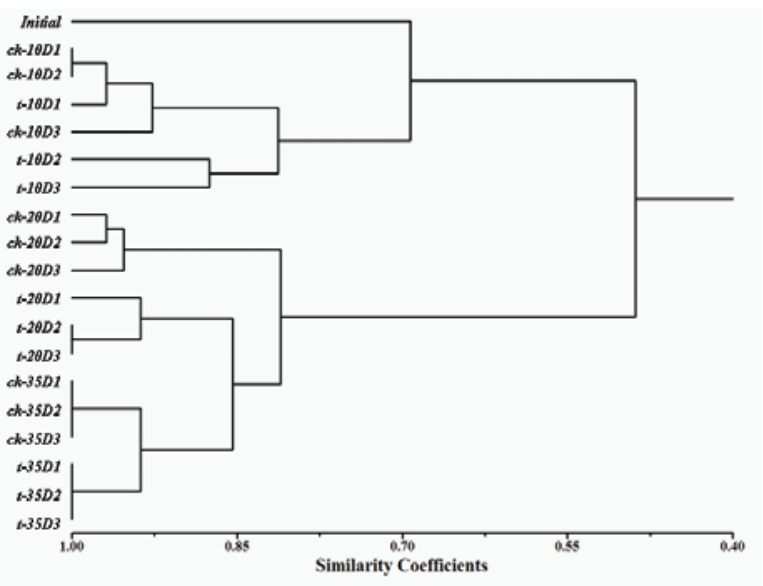

Figure 2: Cluster analysis of the intestinal autochthonous microbiota of ko carp fed Bacillus subtilis C-3102 based on 16S rDNA v3 Denaturing Gradient Gel Electrophoresis (DGGE).

Initial: the initial sample; ck-10D1-3: the triplicates of the control at the end of 10 feeding days; $t-10 D 1-3$ : the triplicates of the Bacillus subtilis C-3102 treatment at the end of 10 feeding days; $c k-20 D 1-3$ : the triplicates of the contro at the end of 20 feeding days; $t-20 D 1-3$ : the triplicates of the Bacillus subtilis C-3102 treatment at the end of 20 feeding days; $c k-35 D 1-3$ : the triplicates of the control at the end of 35 feeding days; $t-35 D 1-3$ : the triplicates of the Bacillus subtilis $\mathrm{C}-3102$ treatment at the end of 35 feeding day.
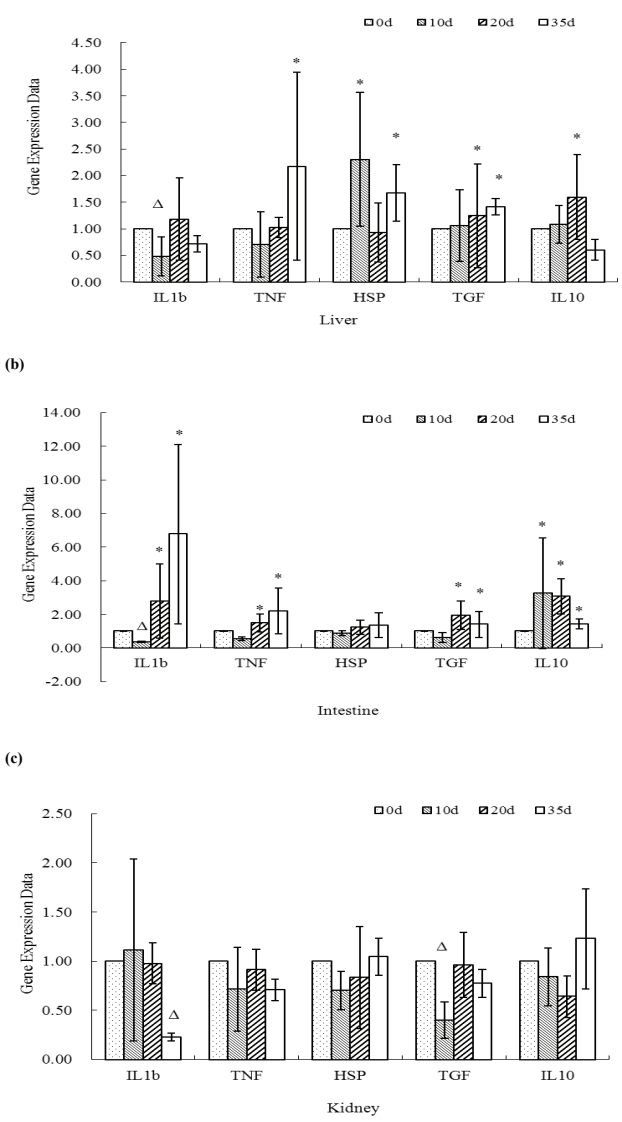

Figure 3: Effects of dietary Bacillus subtilis C-3102 on the immune responses of koi carp. (a) liver; (b) intestine; (c) kidney. The triangles means significantly down-regulated and asterisks means significantly up-regulated.

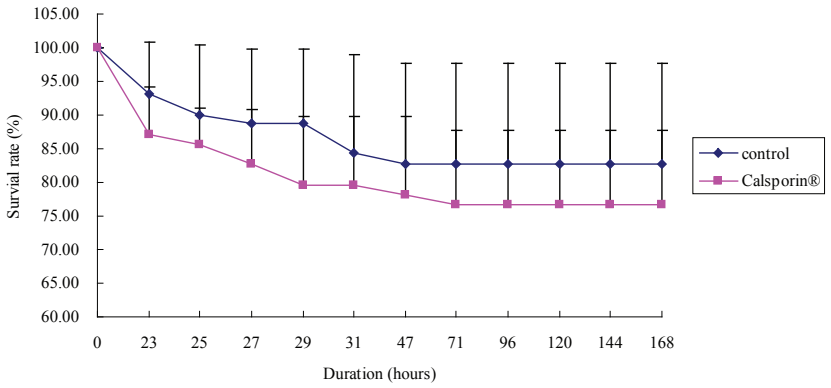

Figure 4: Effect of dietary Bacillus subtilis C-3102 on the survival rate of koi carp infected by Aeromonas hydrophila NJ-1.

in non-specific immune responses. TGF- $\beta$ is a pleiotropic cytokine involved in tissue remodelling, wound repair, development and haematopoiesis, and is expressed in a wide range of cells and tissues. It acts to down-regulate the expression of cytokines and cytokineinduced effects. TNF- $\alpha$ is produced as a transmembrane protein or glycoprotein that is elevated in the extracellular C-terminal domain to release a biologically active mature peptide. Interleukin- $1 \beta$ is a major player in immune response of fish as in mammals. It's a key mediator in response to microbial invasion and tissue injury and can stimulate immune responses by activating lymphocytes or by inducing the release of other cytokines capable of triggering macrophages, NK cells and lymphocytes. Macrophages are the primary source of IL-1 $\beta$ although it is produced by a wide variety of other cell types [31]. As an autoregulatory mediator, IL-10 has important regulatory effects on immunological and inflammatory responses because of its capacity to inhibit the production of proinflammatory cytokines by monocytes [32]. Dietary Bacillus subtilis provided to rainbow trout have previously been reported to have no effects on the expression of the cytokine genes in the spleen and kidney [33], but the cytokine genes were significantly increased in rainbow trout head-kidney leucocytes when incubated in vitro with Carnobacterium maltaromaticum B26 and C. divergens B33 [34]. In the present study, a trend of elevated cytokine gene expression levels was observed in the intestine and liver but were unaffected in the kidney. The reason for the regulation of cytokine genes in fish organ induced by probiotic is not clear. Even though the probiotic was not detected as a prominent member of the gut microbiota from the DGGE analysis, we hypothesize that cell wall components or spores, which were not lysed effectively prior to DNA analysis, were present in the gut which may have stimulated the lymphoid cells in the mucosa to induce changes in the expression of TGF- $\beta$, TNF- $\alpha$ and IL- $1 \beta$ genes. In order to modulate immune response, IL-10 expression was significantly increased $(P<0.05)$ in the immune organs (liver and intestine). According to the previous studies and our results, Bacillus probiotics can cause different effects on cytokine gene expression levels in different organs of fish. Gatesoupe [35] concluded that probiotics for aquaculture should be antagonistic to pathogens and increase resistance of the host to pathogens. However, in our study, B. subtilis C-3102 did not show any protection against $A$. hydrophila, and the reason may be due to the too high dose of A. hydrophila used.

\section{Conclusion}

The results showed that dietary supplementation of B. subtilis C-3102 could provide beneficial effects on koi growth performance, strongly affect the intestinal microbiota at the initial stages (which 
Citation: He S, Liu W, Zhou Z, Mao W, Ren P, et al. (2011) Evaluation of probiotic strain Bacillus subtilis C-3102 as a feed supplement for koi carp (Cyprinus carpio). J Aquac Res Development S1:005. doi:10.4172/2155-9546.S1-005

diminished with time), and elevate the expression of some immune related genes. However, B. subtilis C-3102 did not improve the disease resistance of koi challenged with $A$. hydrophila. Further work is required to determine the function of the cytokine expressions related to host protection against $A$. hydrophila infection and disease recovery.

\section{References}

1. Balcázar JL, de Blas I, Ruiz-Zarzuela I, Cunningham D, Vendrell D, et al. (2006) The role of probiotics in aquaculture. Vet Microbiol 114: 173-186.

2. Nikoselainen S, Ouwenhand AC, Bylund G, Salminen S, Lilius EM (2003) Immune enhancement in rainbow trout (oncorhynchus mykiss) by potential probiotic bacteria (Lactobacillus rhamnosus). Fish Shellfish Immunol 15: 443-452.

3. Kumar R, Mukherjee SC, Prasad KP, Pal AK (2006) Evaluation of Bacillus subtilis as a probiotic to Indian major carp Labeo rohita (Ham.). Aquacult Res 37: 1215-1221.

4. Wang YB, Xu ZR (2006) Effect of probiotics for common carp (Cyprinus carpio) based on growth performance and digestive enzyme activities. Anim Feed Sci Technol 127: 283-292.

5. Venkat HK, Sahu NP, Jain KK (2004) Effect of feeding Lactobacillusbased probiotics on the gut microflora, growth and survival of postlarvae of Macrobrachium rosenbergii (de Man). Aquac Res 35: 501-507.

6. Kim Dh, Austin B (2006) Innate immune responses in rainbow trou (Oncorhynchus mykiss, Walbaum) induced by probiotics. Fish Shellfish Immunol 21: 513-524.

7. Boer AS, Diderichsen B (1991) On the safety of Bacillus subtilis and B.amyloliquefaciens: A review. Appl Microbio Biotechnol 36: 1-4.

8. Wang Y, Li J, Lin J (2008) Probiotics in aquaculture: challenges and outlook Aquaculture 281: 1-4

9. $\mathrm{Ai} \mathrm{QH}, \mathrm{Xu} \mathrm{HG}$, Mai KS, Xu W, Wang J, et al. (2011) Effects of dietary supplementation of Bacillus subtilis and fructooligosaccharide on growth performance, survival, nonspecific immune response and disease resistance of juvenile large yellow croaker, Larimichthys crocea. Aquaculture 317: 155-161.

10. Vaseeharan B, Ramasamy P (2003) Control of pathogenic Vibrio spp. by Bacillus subtili BT23, a possible probiotic treatment for black tiger shrimp Penaeus monodon. Lett Appl Microbiol 36: 83-87.

11. Amabile-Cuevas CF, Cárdenas-Garcia M, Ludgar M (1995) Antibiotic resistance. Anim Sci 83: 320-329.

12. EL-Nobi GA, Reda RM, Hassanin ME, Elmowalid G (2009) The impact of applications of probiotic "Bacillus subtilis" on health and growth of koi carp "Cyprinus carpio". Proceeding of the $2^{\text {nd }}$ Global Fisheries and Aquaculture Research Conference.

13. Dhanaraj M, Haniffa MA, Singh SVA, Arockiaraj AJ, Ramakrishanan CM, et al. (2010) Effect of Probiotics on Growth Performance of Koi Carp (Cyprinus carpio). J Appl Aquacult 22: 202-209.

14. Chandra R, Rajan MR (2009) Probiotic effect of intestinal bacteria of Koi carp Cyprinus carpio var. koi. J Pure Appl Microbiol 3: 363-366.

15. Turner JT, Backman PA, (1991) Factors relating to peanut yield increases after seed treatment with Bacillus subtilis. Plant Disease 75 : 347-353. Full Text via CrossRefTurner and Backman, 1991.

16. Zhou ZG, He SX, Liu YC, Shi P, Huang GX et al. (2009) The Effects of Dietary Yeast Culture or Short-chain Fructo-oligosaccharides on the Intestinal Autochthonous Bacterial Communities in Juvenile Hybrid Tilapia, Oreochromis niloticus $9 \times$ Oreochromis aureus $\hat{}$. J W World Aquacult Soc 40: 450-459.

17. Yu Z, Morrison M (2004) Improved extraction of PCR-quality community DNA from digesta and fecal samples. Biotechniques 36: 808-812.
18. Livak KJ, Schmittgen TD (2001) Analysis of Relative Gene Expression Data Using Real-Time Quantitative PCR and the $2^{-\Delta \Delta C T}$ Method. Methods 25: 402 408

19. Salinas I, Cuesta A, Esteban MA, Meseguer J (2005) Dietary administration of Lactobacillus delbrüeckii and Bacillus subtilis, single or combined, on gilthead seabream cellular innate immune responses. Fish Shellfish Immunol 19: 67-77.

20. Ghosh S, Sinha A, Sahu C (2007) Dietary probiotic supplementation on growth and health of live-bearing ornamental fishes. Aquacult Nutr 14: 289-299.

21. Ghosh S, Sinha A, Sahu C (2007) Effect of probiotic on reproductive performance in female live-bearing ornamental fish. Aquacult Res 38: 518-526.

22. Avella MA, Olivotto I, Silvi S, Place AR, Carnevali O (2010) Effect of dietary probiotics on clownfish: a molecular approach to define how lactic acid bacteria modulate development in a marine fish. Am J Physiol Regul Integr Comp Physiol 298: 359-371.

23. Avella MA, Gioacchini G, Decamp O, Makridis P, Bracciatelli, et al. (2010) Application of multi-species of Bacillus in sea bream larviculture. Aquaculture 305: 12-19.

24. Aly SM, Ahmed YAG, Ghareeb AAZ, Mohamed MF (2008) Studies on Bacillus subtilis and Lactobacillus acidophilus, as potential probiotics, on the immune response and resistance of Tilapia nilotica (Oreochromis niloticus) to challenge infections. Fish Shellfish Immunol 25: 128-136.

25. Al-Harbi AH, Uddin NM (2004) Seasonal variation in the intestinal bacteria flora of hybrid tilapia (Oreochromis niloticus $\times$ Oreochromis aureus) cultured in earthen ponds in Saudi Arabia. Aquaculture 229: 37-44.

26. He SX, Zhou ZG, Liu YC, Shi PJ, Yao B, et al. (2009) Effects of dietary Saccharomyces cerevisiae fermentation product (DVAQUA®) on Growth performance, intestinal autochthonous bacterial community and non-specific immunity of hybrid tilapia (Oreochromisniloticus $9 \times 0$.aureus cages. Aquaculture 294: 99-107.

27. Rahman M, Colque-Navarro P, Kühn I, Huys G, Swings J, et al. (2002) Identification and characterization of pathogenic Aeromonas veronii biovar sobria associated with epizootic ulcerative syndrome in fish in bangladesh. Appl Environ Microb 68: 650-665

28. Avella MA, Olivotto I, Silvi S, Ribecco C, Cresci A, et al. (2011) Use of Enterococcus faecium to improve common sole (Solea solea) larviculture. Aquaculture 315: 384-393.

29. Balcázar JL (2002) Use of probiotics in aquaculture: general aspects. In de Blas, I. (Ed.), Memorias del Primer Congreso Iberoamericano Virtual de Acuicultura, Zaragoza, Spain, pp. 877-881.

30. Chang Cl, Liu WY (2002) An evaluation of two probiotic bacterial strains Enterococcus faecium SF68 and Bacillus toyoi, for reducing edwardiellosis in cultured European eel, Anguilla anguilla L. J Fish Dis 25: 311-315.

31. Secombes CJ, Wang T, Hong S, Peddie S, Crampe M, et al. (2001) Cytokines and innate immunity of fish. Dev Comp Immunol 25: 713-23.

32. de Waal Malefyt R, Abrams J, Bennett B, Figdor CG, de Vries JE (1991) Interleukin 10(IL-10) inhibits cytokine synthesis by human monocytes: an autoregulatory role of IL-10 produced by monocytes. J Exp Med 174: 12091220.

33. Panigrahi A, Kirona V, Satoha S, Hirono I, Kobayashi T, et al. (2007) Immune modulation and expression of cytokine genes in rainbow trout Oncorhynchus mykiss upon probiotic feeding. Dev Comp Immunol 31: 372-382.

34. Kim Dh, Austin B (2006) Cytokine expression in leucocytes and gut cells of rainbow trout, Oncorhynchus mykiss Walbaum, induced by probiotics. Vet Immunol Immunopathol 114: 297-304

35. Gatesoupe FJ (1999) The use of probiotics in aquaculture. Aquaculture 180 147-165.

This article was originally published in a special issue, Probiotic \& Prebiotic Applications in Aquaculture handled by Editor(s). Dr. Daniel L. Merrifield, University of Plymouth, UK; Prof. Zhigang Zhou, Chinese Academy of Agricultural Sciences, China 